\title{
Brief Contents
}

$\begin{array}{ll}\text { Introduction } & 1\end{array}$

\1. Issues 3

\2. Identifying the Governing Rule of Law 22

\3. Levels of Abstraction 35

\4. Deduction $\quad 65$

$\begin{array}{ll}\int 5 . \text { Induction } & 88\end{array}$

\6. Arguments in General 105

\ 7. Arguments Classified by Function $\quad 114$

\8. Arguments Based on Evidence 122

\9. Policy Arguments 124 
\$10. Doctrinal Arguments

$\mathbb{\$} 11$. Analogies and Precedents

\12. Distinctions

$\$ 13$. Holding and Dictum

\$14. Reductios ad Absurdum

$\$ 15$. Subjective and Objective Standards

$\mathbb{\$} 16$. Interpreting Statutes

\$17. Prima Facie Case, Affirmative Defense, Burden of Proof

$\mathbb{\$} 18$. Application of Law to Fact

\$19. A Model of Legal Argument 285

Answers 